\author{
RICCARDO FEDRIGA * \\ ORCID: 0000-0002-2291-7800 \\ ROBERTO LIMONTA ** \\ ORCID: 0000-0003-2407-1746
}

\title{
ASSENSUM IN MENTE PROPHETAE: WILLIAM OF OCKHAM AND WALTER CHATTON ON PROPHECIES
}

\author{
Keywords: Walter Chatton, William of Ockham, Prophecy, Assensum, \\ God's Foreknowledge, Future Contingents, Externalism
}

\footnotetext{
* Riccardo Fedriga - Graduated in Milan and specialized in Copenhagen and Paris, he became researcher and then associate professor of Medieval Philosophy at Alma Mater Studiorum-University of Bologna, where he works and teaches. His philosophical interests concern the theory and history of intentionality, the problem of free will, akrasia and theological compatibilism, and the theme of prophecies in fourteenth-century theology. Author of several studies on philosophy and history of ideas (La filosofia e le sue storie, 3 vols. with Umberto Eco), he has recently published the Italian edition of Tractatus de praedestinatione et praescientia divina respectu futurorum contingentium by William of Ockham (Roma 2020) with R. Limonta.

Address for correspondence: Via San Primo 1a, 23887 Olgiate Molgora (Lecco), Italy. Email: riccardo.fedriga@unibo.it.

** Roberto Limonta-Honorary fellow (cultore della materia) at the Alma Mater Studiorum-University of Bologna. Topics of his research are theology and philosophy of language in the Western Monastic tradition and the late Middle Ages, with particular reference to omnipotence, foreknowledge, prophecies and future contingents. Recent publications include Il Trattato sulla predestinazione e prescienza
} 
The theological debate between Chatton and Ockham about prophetic statements can be usefully approached by stating two key assumptions. First, the question about the truth-value of prophecies fits into a broader issue within the theological framework of the early 14th century debate that Russell Friedman has effectively described as the "search for simplicity." Indeed, the discussion on prophecies undergoes a significant paradigm shift during the transition from the 13 th to the 14th century, moving as it does from the psychological approach of Albert the Great and Thomas Aquinas, who link the inquiry to an analysis of the soul's faculties, to the linguistic framework employed by Ockham and Chatton. For them, prophecies have to be intended from a linguistic point of view, that is, focusing on the sentences' structure more than on events described. ${ }^{2}$ Second, we intend to apply the epistemological externalism/internalism distinction ${ }^{3}$ to prophetic statements as a case study to show that assessing the degree of externalism displayed by Ockham

divina riguardo ai futuri contingenti di Guglielmo di Ockham, co-author R. Fedriga (Roma 2020) and the Italian edition of Peter Damian's De divina omnipotentia (Milano 2020).

Address for correspondence: Via Giuseppe Dossetti 15, 20097 San Donato Milanese (Milano), Italy. Email: limonta@libero.it.

1 Friedman, 2013, p. 597: "God's absolute simplicity [has to be intended as] the most important goal in Trinitarian theology.” See also Slotemaker, 2015, p. 689.

2 Rodolfi, 2016, pp. 24-35 and pp. 194-212; Torrell, 1992, particularly pp. 558-560; Vauchez, 1990, pp. 291-683.

3 "Epistemological" has to be intended, here, according to what William Courtenay defines as "covenantal theology", particularly in the case of social justification and acceptation of prophetic statements, see Courtenay, 1972, p. 186, note 3: "The concept of covenantal causality is not a small point in sacramental theology but rather one of the fundamental principles of the Nominalist worldview. Although not created by the Nominalists, it was utilized by Ockham and his followers to solve a wide variety of theological problems." The covenantal theory of sacramental causality was based on a belief that certain causal relationships depend for their efficacy on nothing more than a contract or a more general ordination, agreement, or understanding that is accepted by all persons concerned. For a brief definition of the internalism and externalism distinction that we use in this article, see Pappas, 2014: "Internalism in the first instance is a thesis about the basis of either knowledge or justified belief. [...] A second form of internalism, connected just to justified belief but probably extendable to knowledge as well, concerns not access but rather what the basis for a justified belief really is. Mentalism is the thesis that what ultimately justifies any belief is some mental state of the epistemic agent holding that belief. Externalism on this dimension, then, would be the view that something other than mental states operate as justifiers." 
and Chatton's theories helps verify their internal coherence and efficacy with reference to their declared goals. As we shall see, (epistemological) realism and externalism do not necessarily coincide. In the search for divine simplicity, prophecies show (i) that the interplay between Ockham and Chatton is based on direct realism, but (ii) include different degrees of externalism depending on the ontological commitments of the different theories.

Let us start with the second point, namely externalism and ontological commitment. Recently, the distinction between externalism and internalism has been at the center of a debate on Ockham's theory of knowledge, with particular reference to acts of direct apprehension or intuitive cognition (notitia intuitiva). We shall not dwell here on the various positions that frame the current discussion, though we will make occasional reference to them. ${ }^{4}$ Rather, we shall focus on a specific issue that has led a crucial role within the debate between externalism and internalism, and which may be expressed as follows: if and only if, in Ockham's view, an intuition is the cognitive act through which one apprehends that a thing exists when it exists, and if the truth-maker of such a cognition is the direct and causal action of a res upon the knower's cognitive faculties, how is it possible (if at all) to have intuition of a non-existing or not yet present thing (cognitio intuitiva de re non existente), as in the case of prophecies? ${ }^{5}$

For at the heart of the question there lies a notion of intuition that lacks a corresponding object and yet is certain - accordingly to the act through which God generates in the viator's mind, namely the assent to a proposition which stands for (supponit pro) a thing's existence. Prophecies, that is to say statements that are necessarily true though they describe non-actual states of affairs, thus provide a fruitful case study to examine and legitimize the scientific status of theological knowledge as a science (i) either in the sense of the first definition of scientia in the prologue of Ockham's Expositio

${ }^{4}$ See Brower-Toland, 2007, pp. 317-336; Brower-Toland, 2015, pp. 204-234; Brower-Toland, 2017, pp. 59-80; Fedriga, 2019, pp. 19-47; Karger, 2015, pp. 186-203; Klima, 2010, pp. 99-110; Normore, 2017, pp. 81-94; Panaccio, 2010, pp. 241-243; Panaccio, 2014, pp. 55-74; Panaccio, 2015, pp. 166-185.

5 See Karger, 1999, pp. 204-226; Karger, 2004, pp. 225-236; Pasnau, 1997; Tachau, 1988, pp. 123-129. 
in libros Physicorum ${ }^{6}$ or (ii) in the sense of a soft implication ("bringing about") between theological statements and the states of affairs they refer to. ${ }^{7}$

\section{Future Contingents and Prophecies: Ockham's Position}

Ockham tackles the problem of prophecy principally in the Tractatus de praedestinatione et de prescientia dei respectu futurorum contingentium, even if some important remarks can also be found in the fourth question of the Quodlibeta Septem. ${ }^{8}$ His analysis works at the level of the logic of propositional rules: a prophecy is understood not as a cognitive state as it was in Aquinas's Quaestiones disputatae de Veritate, ${ }^{9}$ but as a contingent statement about future events, whose truth-value is determined by revelation. Ockham asks whether prophetic revelations "necessarily happen in the way they were revealed or not."

${ }^{6}$ Guillelmus de Ockham, Expositio in libros physicorum, Prologus (ed. Richter, Leibold, 1985, p. 5: 29-34): "Una est quod scientia uno modo est certa notitia alicuius veri; et sic sciuntur aliqua per fidem tantum. Sicut dicimus nos scire quod Roma est magna civitas, quam tamen non vidimus; et similiter dico quod scio istum esse patrem meum et istam esse matrem meam, et sic de aliis quae non sunt evidenter nota; quia tamen eis sine omni dubitatione adhaeremus et sunt vera, dicimur scire illa." As we shall see, the role of faith is crucial for the pragmatic and performative use of prophetic statements. About faith as a habitus, see Courtenay, 1990, p. 124.

7 About the notion of "bringing about" as a kind of "soft implication", see Dummett, 1964, pp. 338-359. For an implicit source of this interpretation of causality in Ockham's thought, see Guillelmus de Ockham, Quodlibeta Septem, VI, q. 2 (ed. Wey, 1980, p. 591: 47-55): "Secundo dico quod de necessitate [Deus] acceptat actum elicitum ex caritate, loquendo de necessitate ex suppositione, quia haec consequentia est necessaria: Deus ordinavit et instituit per leges iam datas quod talis actus sic elicitus sit acceptandus, igitur Deus illum actum iam elicitum acceptat; quia antecedens non potest esse verum sine consequente, et tamen tam antecedens quam consequens est simpliciter contingens. Sicut ista consequentia est necessaria: Petrus est praescitus, igitur Petrus damnabitur; et tamen tam antecedens quam consequens est simpliciter contingens."

${ }^{8}$ Guillelmus de Ockham, Tractatus de praedestinatione et de praescientia Dei respectu futurorum contingentium (= Tractatus de praedestinatione), q. I, d. 8 (ed. Boehner, Brown, 1978, p. 513: 163-182); cf. also Guillelmus de Ockham, Quodlibeta Septem, IV, q. 4 (ed. Wey, 1980, pp. 314-319). On prophecies and future contingents in Ockham's work, in particular in the Tractatus de praedestinatione, see Fedriga, Limonta, 2019.

${ }^{9}$ See question 12 "De prophetia" in Thomas de Aquino, Quaestiones disputatae de veritate (ed. Dondaine, 1970-1976, pp. 365-414). 
The key issue concerns the fatalistic implications that derive from propositions whose truth-value is guaranteed by their being objects of divine revelation but which, as far as their content is concerned, are still about indeterminate and "open" states of affairs. The issue of prophecy is addressed by means of a distinction that operates along two planes. First of all, there is the ontological plane, in which Jonah the prophet (Ockham's example) prophecies at $\mathrm{T}_{1}$ that event $p$ will occur at $\mathrm{T}_{2}$. In order for this statement to be recognized as a prophecy, it is necessary to wait for the occurrence of event $p$ at $\mathrm{T}_{2}$; but the need for such a verification - which will be obtained only a posteriori-does not detract from the fact that even at $T_{1}$ the statement " $p$ will occur at $\mathrm{T}_{2}$ " was to be considered a true prophecy. ${ }^{10}$ Determinism, however, is ruled out, for the statement will be recognized as true only on a different, temporal/epistemological plane - that is, when it is possible to verify that the predicted state of affairs has actually taken place.

Prophecies, therefore, seem to belong with those statements to which one may apply Ockham's distinction between past-tensed propositions secundum rem (i.e., propositions about events that actually took place in the past and are thus fixed by necessity, such as 'Caesar crossed the Rubicon yesterday') or secundum vocem (i.e., propositions that are only verbally about the past, such as 'Peter was predestined to salvation'). ${ }^{11}$

${ }^{10}$ Guillelmus de Ockham, Tractatus de praedestinatione, q. 1, d. 8 (ed. Boehner, Brown, 1978, p. 513: 170-182): "Dico quod nullum revelatum contingens futurum evenit necessario sed contingenter. [...] omnes prophetiae de quibuscumque futuris contingentibus fuerunt condicionales, quamvis non semper exprimebatur condicio. Sed aliquando fuit expressa, sicut patet de David et throno suo; aliquando subintellecta, sicut patet de Ninive destructione a Iona prophetata: Adhuc post quadraginta dies et Ninive subvertetur, nisi scilicet poeniterent; et quia poenituerunt, ideo non fuit destructa."

${ }^{11}$ Guillelmus de Ockham, Tractatus de praedestinatione, q. 1, s. 3 (ed. Boehner, Brown, 1978, p. 515: 208-220): “[...] aliquae sunt propositiones de praesenti secundum vocem et secundum rem, et in talibus est universaliter verum quod omnis propositio de praesenti vera habet aliquam de praeterito necessariam, sicut tales: 'Sortes sedet', 'Sortes ambulat', 'Sortes est iustus', et huiusmodi. Aliquae sunt propositiones de praesenti tantum secundum vocem et sunt aequivalenter de futuro, quia earum veritas dependet ex veritate propositionum de futuro; et in talibus non est ista regula vera quod omnis propositio vera de praesenti habet aliquam de praeterito necessariam. Et hoc non est mirabile, quia sunt propositiones verae de praeterito et de futuro quae nullam habent veram de praesenti, sicut istae 'album fuit nigrum', 'album erit nigrum', quae sunt verae, et sua de praesenti est falsa, scilicet ista album est nigrum'.” Unless otherwise stated, all translations are our own. 
The prophetic sentence uttered at $\mathrm{T}_{1}$, e.g., 'Petrus praedestinatur', requires that the predicted event take place at $\mathrm{T}_{2}$; thus, while the sentence may be said to be true already today at $\mathrm{T}_{1}$, insofar as it is guaranteed by the divine auctoritas that revealed it, it still needs to be completed by a series of intentional acts that determine the actual occurrence at $T_{2}$ of the state of affairs described at $\mathrm{T}_{1}$. It must therefore be understood as a proposition that is only verbally about the present, and as such escapes both Aristotle's necessity of the present and the necessitas per accidens of the past. ${ }^{12}$

A prophetic statement, therefore, does not describe at $T_{1}$ a fact that is completely determined at $\mathrm{T}_{2}$, but defines the truth conditions of a futuretensed statement that always presents itself as an "implicit conditional proposition." In case the event that functions as a premise takes place, the conditional proposition shall be true and necessarily so. The prophecy predicts the actual occurrence of an event in the following manner: the event will (necessarily) take place in case a (contingent) combination of situations occurs, which causes the event to become real. Thus, in Ockham's view, the truth-value of prophecies is that of necessitas consequentiae, i.e., the necessity that follows from the logical implication between two propositions, and not the truth-value expressed by the necessitas consequentis, which presupposes that the future event will deterministically occur.

A prophecy institutes a relationship between the propositional complex and the res, in the absence of the res themselves. Prophetic statements, therefore, refer by virtue of suppositio to states of affairs that are real to divine cognition, but are not yet so in actuality - at least as far as the human intellect is concerned. The implicitly assumed premise is that the divine subject that uttered the prophecy provides sufficient guarantee for the inferences that one may draw from prophetic statements to accept and justify meritorious acts. The inferential process's foundation thus remains externalist: the "intentional" act of belief does not grasp any mental object to which the viator's mind turns and immediately assents, but anchors the inferential chain to the plane of res, even though the state of affairs (the res) is absent from the prophet's mind - for it is, however, present in the mind of God, which

12 Cf. Guillelmus de Ockham, Quodlibeta Septem, IV, q. 4 (ed. Wey, 1980, p. 316 : 43-46). For Aristotle on necessity of the present and the past, see De Interpretatione, 9, 18a 28-34 (ed. Migliori, 2016, p. 228). 
guarantees its truth-value. Still, prophecy is a divine truth that is expressed through the rules of human language.

Ockham's account may thus be defined as a kind of externalism ${ }^{13}$ that alleviates the rigid direct reference to the res through language, in particular categorematic and, above all, syncategorematic terms. ${ }^{14}$ The latter, indeed, though derived from conventional human languages, may provide the rule for forming true propositions, which, though expressed as statements, correspond to God's non-verbal and non-propositional knowledge. This is made possible, for Ockham, by the relationship of reverse subordination: ${ }^{15}$ concepts are subordinate to words, and this results into a semantic redefinition and a new employment of those concepts within propositions. One may thus affirm that in certain cases the signification of concepts takes place at the level of language pragmatics, since it depends on the conventional use the speaker makes of them.

The Ockhamist analysis of future contingents, prophecies and the intuitive cognition of non-existing things more shows the possibility of developing counterfactual logical models capable of guaranteeing a direct apprehension of the individual thing. This scenario, which as we shall see Chatton shares, is grounded in the following theses: (1) the meaning of words does not depend in the first instance on what we have in mind when we use them; (2) the content of our thoughts depends on the causal chain that produced those mental states; (3) the mere reference to mental states does not allow us to distinguish knowledge from belief, since this difference is grounded in the fact that these two kinds of knowing produce different kinds of causal chains.

${ }^{13}$ For the different forms of externalism (linguistic, mental content and epistemic externalism), see Panaccio, 2015, pp. 166-167.

${ }^{14}$ Categorematic terms have signification independently from other words. Syncategorematic terms such as "not", "and", or "if" need other words to have meaning within a statement. The latter kind of term has a crucial role, because they make possible the logical articulation of the proposition.

15 See Panaccio, 2015, pp. 179-180: "The process Ockham postulates, in short, is a reverse subordination. Instead of subordinating a spoken word to a concept, we now subordinate a concept to a spoken word. And as a result, we can use this concept in our mental propositions with this new signification, just as with any other mental term. [...] The suggestion, moreover, brings us a step further into externalism. What we are led to, if we follow the hint, is that the signification of some of our concepts can depend upon the conventional imposition of certain words by other speakers." About this topic, see also Fedriga, 2019. 
Although Ockham did not set out these three theses as parts of a single unified theory, it is undeniable that they, even taken singularly, point to what seems prima facie an externalist framework. But if this reading of Ockham is correct, we can admit a cognitive theory purely grounded in causal processes that does not need the metaphysical assumption of a causal theological determinism or temporal necessitas per accidens, where causal processes are necessarily linked to the existence of external things. In the case of prophecies, consistent with the principle of parsimony and divine simplicity, the causal chain in question simply describes the operative mode of the cognitive process in the absence of any external object. Ockham's omnipotent God can shorten or even annihilate the process that leads to the evident cognition (notitia evidens) of a not (yet) existing thing. In fact, Ockham admits the theological principle according to which God can cause, by himself, the effect of any other cause. ${ }^{16}$ This short path makes clear the real nature of this process, which is not in the natural course of things. Indeed, the difference between intuitive and abstractive cognition does not lie in their object, but in their effect. As Susan Brower-Toland rightly points out,

Ockham's appeal to the counterfactual dependence of an intuitive state on its natural cause is motivated by his views about the nature of causal dependence in general. And, as we have now seen, Ockham holds that such dependence is grounded in certain essential dispositional features of the effect-features that would remain even when its natural or de facto cause does not exist, or at least does not produce it. It is precisely these dispositional features of the effect that the supernatural cases highlight. Even when a given effect-an intuitive cognition, say - is produced by God acting alone, it will by nature be such that it is counterfactually causally dependent on its natural cause. ${ }^{17}$

In this context, phenomena such as miracles, prophecies, future contingents, sensory illusions, and the direct apprehension of absent or non-existing things are no longer objects of research for determining their psychological or epistemological status, and there is no longer any question as to which

16 Ockham defines intuition as a kind of cognition by virtue of which one knows that a thing exists when it exists, and that it does not exist when it does not exist. Intuitive cognition of non-existents may therefore occur, but such acts are supernaturally caused by God acting alone to produce them in an intellect.

17 Brower-Toland, 2017, p. 71. 
function of the soul they belong, and how they are produced, for example, in causal processes. Rather, this kind of event is understood as a test to verify the coherence and stability of theories about the divine order of the world. ${ }^{18}$

\section{Belief as Regula: Logic and Pragmatics of Prophecy}

In the prologue to the Expositio in libros Physicorum, Ockham lists four possible definitions of scientific knowledge (scientia), which go back to Aristotle. The first claims that science may be identified with knowledge grounded on assent given to propositions that are considered true. ${ }^{19}$ Divine auctoritas, expressed in fide digni statements (called suppositiones by Ockham), functions in this case as the necessary premise (regula $)^{20}$ that leads the argumentative chain to true conclusions in the modern sense of 'necessary hypothesis' or 'postulate', which is the meaning attributed to the term suppositio in many 13th-century commentaries on the Posterior Analytics. ${ }^{21}$

Such an auctoritas constitutes a normative and prescriptive ground that can indicate the correct way of performing cognitive acts and the will's choices (in the sense expressed by Michael Dummett's notion of "bringing about") without thereby causally determining the contents and truth-values of our items of knowledge. In Ockham's view, therefore, prophecies are to be understood as 'signs' starting from the certainty of the ground, which functions as a rule. Prophecies supply a paradigmatic model for the way the things must connect to one another through cognitive acts, as explained in the Ordinatio; at the same time, they function as precepts whose normative force applies to human conduct on the path to salvation. Prophecies are thus

\footnotetext{
18 On this meaning of ordinatio, see Courtenay, 1990, p. 121.

19 Guillelmus de Ockham, Expositio in libros physicorum, Prologus (ed. Richter, Leibold, 1985, pp. 5-6: 29-34).

${ }^{20}$ In the Summa logicae Ockham employed the term regula to name the guarantee of correctness on the basis of which an argumentative chain can arrive at true conclusions; see Guillelmus de Ockham, Summa logicae (ed. Boehner, Gál, Brown, 1974, p. 334: 10-14).

${ }^{21}$ It must be pointed out that the term suppositio understood in this way has a different meaning from the one it usually has in Ockham's works. In the Summa logicae, for instance, the term suppositio indicates the referential property that allows words to replace things within propositions, directly anchoring the logical plane to the ontological one.
} 
linguistic indications - or norms - that outline what might be defined as the "pragmatics of a theological language". 22

The Venerabilis Inceptor's position crucially hinges on the notions of acts of belief and logical-demonstrative procedures. This is made evident by another locus on prophecies, which has received less attention than the Tractatus. It is the fourth question of the fourth Quodlibeta Septem (Utrum Deus possit revelare alicui notitiam evidentem futurorum contingentium), particularly the third dubium concerning qualem notitiam habuerunt prophetae de facto talium futurorum:

[o]ne can reply that the prophets had this sort of evident knowledge of future contingents. Alternatively, one can reply that God revealed such truths to them simply by causing faith in them. But I do not know what in fact the case is, since this has not been revealed to me. ${ }^{23}$

In the context of prophecies, the role of ground is performed by the certainty of revelation and thus by the divine world-order; they are not simply objects of the believer's faith, but they constitute the premises of an argumentative procedure in the modern sense of "necessary hypotheses" or "postulates". The auctoritas of prophetic statements - and their source, that is to say divine foreknowledge - are thus both necessary and indemonstrable, and in this respect they are similar to the postulates of Euclidean geometry. ${ }^{24}$ Prophetic revelation is an act that produces knowledge in the form of an assent (fidem, endowed with truth) ${ }^{25}$ given to statements whose terms immediately replace states of affairs, even though such an assent

22 On the pragmatic meaning of the prophecies, see Piron, 2014, pp. 255-286.

${ }^{23}$ Guillelmus de Ockham, Quodlibeta Septem, IV, q. 4 (ed. Wey, 1980, p. 318: 92-95; trans. Freddoso, Kelley, 1991, p. 262).

24 At the end of the first question of the Tractatus de praedestinatione Ockham uses suppositio but not to indicate the referential property of a term in the context of the proposition (see Guillelmus de Ockham, Summa logicae, ed. Boehner, Gál, Brown, 1974, pp. 11-12), but as synonymous with "postulate", following William of Moerbeke's translation of the Aristotelian term "hypothesis" (Aristoteles, Analytica Posteriora, I [A], 10, 76 b [ed. Migliori, 2016, p. 892: 23-29]). See also William of Ockham, Predestination, God's Foreknowledge, and Future Contingents, q. 1 (ed. McCord Adams, Kretzmann, 1979, pp. 45-53), where suppositio is always translated as "assumption".

25 See the first definition of scientia in Guillelmus de Ockham, Expositio in libros physicorum, Prologus, § 2 (ed. Richter, Leibold, 1985, pp. 5-6: 29-34). 
cannot become in turn an object of knowledge, since it is not an object but a mental state that allows one to gain access to states of affairs.

In this case, the Venerabilis Inceptor's position seems to be an externalist one: intuitive cognition is always an act through which the intellect turns to things directly. However, in responding to Claude Panaccio, Susan Brower-Toland has convincingly pointed out two cases that Ockham accepts and that undermine a purely externalist reading of his theory of perceptual knowledge: namely, the case of the intuition of a distant thing, which is caused by God, and the case of the intuition of a non-existing object or no longer existing object, which is conserved by God. ${ }^{26}$ To these two, we may add the case of prophecy. As we saw, in Ockham's view prophecies cannot be understood as holding a merely descriptive function. Insofar as they are implicit conditional statements, they predict the viator's capacity to correctly connect the terms of the statements that come from God's knowledge and use them as a moral guide. In this context, the connection is operated by syncategorematic terms like si or et, as we shall see in Chatton's theory. These terms, which derive from the syntax of historical languages, perform an essential semantic and pragmatic function from both a moral and a cognitive point of view. They give the will a directive and allow the intellect to correctly connect the terms in formulating statements.

\section{Res as Truth-Makers: Prophecies and Cognitive Questions in Chatton's Reportatio}

Ockham's specific position is shaped by the interaction of two conversational communities ${ }^{27}$ a diachronic and a synchronic one. The former is provided by the theological tradition on prophecies, which started in the 12th and 13th centuries as a reflection on the status and function of the soul's cognitive faculties but gradually shifted over the course of the 13th and 14th centuries, finally taking a "linguistic turn" with William of Ockham, whose position

\footnotetext{
26 Brower-Toland, 2007, pp. 326-327.

27 For the sense, here, of the term "conversational community", see Gelber, 2004, pp. $12-21$.
} 
was to become the opinio communis within the 14th-century theological debates on prophetic statements. ${ }^{28}$

Ockham's synchronic conversional community, on the other hand, is supplied by the theological-philosophical debates taking place in Oxford in the first two decades of the 14th century, which revolved around the distinction between intuitive and abstractive cognition, and the epistemological problems that issue from that distinction. A vast number of scholars and theologians formed the Oxonian community, at different times and in different ways. We may roughly group them as follows: Henry Harclay, William of Alnwick and Richard Campsall, who were active before Ockham's arrival; Robert Graystanes, John of Reading, Hugh Lawton, John of Rodington, Richard FitzRalph and Walter Chatton, who animated the debate in the first two decades of the 14th century; and finally, Robert Holcot, William Crathorn and especially Adam Wodeham, representing the generation of scholars active in the $1330 \mathrm{~s}^{29}$

Here, we shall focus on the position held by Walter Chatton, with whom Ockham engaged in a constant critical exchange. We shall refer in particular to the distinctions 38-41 from the first book of the Reportatio Super Sententias and the questions 26-29 from the Quodlibeta. ${ }^{30}$ The first point to consider is the relationship between res and statements in the case of prophecies. In Quaestio Secunda, article 1 of distinctions 40-41 in the Reportatio, Chatton focuses on the act through which divine intellect gives its assent to a state of affairs, thus certifying its truth. Chatton wonders whether such an assent is given to a propositional complex or rather directly to things. The answer leaves little room for doubt:

[i]t is not necessary that one always assents to a complex, but one can assent to the thing immediately signified by the complex; and for this

${ }^{28}$ For a brief account of the theories on prophecy between the 13th and the first half of the 14th century, and for a summary bibliography, see Fedriga, Limonta, 2015, pp. 399-401.

${ }^{29}$ Grellard, 2014, pp. 61-108; Perini Santos, 2006, pp. 57-128; Tachau, 1988, pp. 157-314.

30 See Gualterus de Chatton, Reportatio super Sententias: super Librum I (= Reportatio) (ed. Wey, Etzkorn, 2002). We would like to thank Rondo Keele for having made the transcription of the questions 26-29 from the manuscript (Paris BN MS lat. 15805, ff. 54ra-6orb. 26) of the Quodlibeta available to us. 
reason, in order that God assent to a thing signified by 'a is', it is not necessary that God assents to the proposition but to the thing. ${ }^{31}$

A similar non-propositional answer is given to the question concerning divine knowledge: "God does not assent to a thing mediately by assenting to a proposition but to the thing immediately." 32

Let us dwell on divine knowledge in particular, since in Chatton's view this is the model for any other form of knowledge. Divine knowledge is not to be understood as an act that is separate from God himself. Thus, the statement 'God cognizes $a$ ' simultaneously attests to and certifies the existence of an omniscient God and the fact that the contingent fact $a$ will occur. These are expressed by the two statements 'There is an omniscient God' and 'The contingent state of affairs $a$ will occur'. ${ }^{33}$ Each statement, in order to be true, must be anchored to the temporal instant (whether past, present or future) in which the state of affairs it describes is real. For this reason, the statement 'This is true, that Socrates will be seated' cannot be true, for it needs a truth-maker in the present when the state of affairs $a$ (the being seated of Socrates) is not yet in the present. By contrast, the statement 'This will be true, that Socrates is seated' is true.

\section{Assent, Prophecy and Temporality}

In Chatton's account, assent - and the temporal mode of its relation to the state of affairs it refers to - are the key aspects of the cognitive process involved in prophetic statements. In distinction 38 of the Reportatio, when talking about prophecy in the context of divine foreknowledge, Chatton

31 Gualterus de Chatton, Reportatio, qq. 40-41, q. II, art. 1 (ed. Wey, Etzkorn, 2002, p. 395): "[n]on oportet assensum esse semper complexo, sed potest esse immediate rei significatae per complexum; et ideo ad hoc quod Deus assentiat rei significatae per istam 'a est', non oportet quod assentiat propositioni, sed rei."

32 Gualterus de Chatton, Reportatio, qq. 40-41, q. II, art. 1 (ed. Wey, Etzkorn, 2002, p. 395): "Deus non assentit rei mediante assensu propositioni, sed rei immediate."

33 Cf. Keele, Pelletier, 2018: "Chatton's view is that the necessity we detect in 'God knows a' attaches to God as a necessary cognizer, i.e., it attaches to the divine intellect alone, not to the objects it cognizes or to some distinct, determinate body of truths called 'God's knowledge'. It is almost as if, for Chatton, 'God cognizes [future contingent] a' simply means, 'the all-seeing God exists and contingent a will exist'." 
claims that "there is no adequate mode to express divine foreknowledge" 34 and then specifies:

When God causes assent in the prophet's mind about a thing that will be, that assent is true, otherwise God could not make sure the prophet about future things. And that assent has the same meaning of the statement "this thing will be"; therefore, if the assent is true, the statement will be true. ${ }^{35}$

The (necessarily true) assent that God induces in the prophet's mind does not produce in it a cognitive act whose truth-value is fixed by the actual or present occurrence of the relevant state of affairs. Rather, it certifies, on the one hand, that the res are disposed as the terms which, in the linguistic context of the complexum, substitute for them, and, on the other, that it is in the future: "God does not cause the assent in the mind of the prophet by which he assents that it [the thing] is in reality but that it will be in reality." 36

The stress that Chatton places on temporality is decisive because in his view it is the simultaneity between states of affairs or occurrences that functions as the truth-maker's rule, as well as the statement itself. That is, the complexum is true only when it is capable of grasping a present state of affairs, which is different from Ockham's view. In distinction 38 of the Reportatio, the statement 'God knows $a$ will be' must be understood as equivalent to 'God knows this, and it will be'. ${ }^{37}$ The key here is the syncategorematic term "and", which links divine cognition to the occurrence of the "true" state of affairs, and is thus what makes the inference true. The term "and", joining as it does the two statements, determines a simultaneity relationship that is also a logical implication.

${ }^{34}$ Gualterus de Chatton, Reportatio, d. 38, q. u. (ed. Wey, Etzkorn, 2002, p. 350, n. 13).

35 Gualterus de Chatton, Reportatio, d. 38, q. u. (ed. Wey, Etzkorn, 2002, p. 350, n. 16): "[quando] Deus causat assensum in mente prophetae de re quae erit, ille assensus est verus, aliter Deus non posset certificare prophetam de re futura. Et ille assensus significat idem cum propositione tali 'haec res erit'; igitur si assensus est verus, propositio erit vera."

${ }^{36}$ Gualterus de Chatton, Reportatio, d. 38, q. u. (ed. Wey, Etzkorn, 2002, p. 350, n. 16): "Deus non causat in mente prophetae assensum, quo assentiat sic esse in re, sed sic esse venturum in re."

37 Gualterus de Chatton, Reportatio, d. 38, q. u., art. 1 (ed. Wey, Etzkorn, 2002, p. 352 , n. 28). 
On the two sides of the syncategorematic term, the ontological component ('this will be') has priority over the epistemological one ('God knows this'). From the point of view of human temporality, divine cognition precedes the coming of the Anti-Christ, since God's acts of apprehension exist from eternity. With respect to a statement's truth, the states of affairs precede the uttering in the case of prophecies and future contingents. The correspondence between statement and state of affairs is the truth-maker of divine knowledge too, though the latter always has all occurrences in the eternity of its present in view; this is what guarantees the necessary, universal and timeless character of its truths.

When prophecies are considered from the point of view of human apprehension, the prophet's assent (and thus his knowledge) is not aimed at the future state of affairs but always at their actual occurrence: the prophet does not assent to a future occurrence, but to the moment in which that occurrence becomes present in the future. Before the state of affairs is realized, the assent is 'neither true nor false'. ${ }^{38}$ This does not entail that the prophet has scientific knowledge of the thing in the sense of having complete knowledge of it, but only that he has a cognition of it, i.e., merely an apprehension of the thing. ${ }^{39}$ It is the divine auctoritas that, in the form of a testimony, guarantees the correspondence between terms, statements and res that are not yet actual.

\section{The Causal Power of the Res}

Thus, language functions as a guide for ontology. It points us towards those res that constitute the truth-makers of linguistic statements; and this justifies Chatton's interest for the mechanisms that regulate the functioning of terms and propositions. Meaning and reference are not located on two different

${ }^{38}$ Gualterus de Chatton, Reportatio, d. 40-41, q. 1, art. 2 (ed. Wey, Etzkorn, 2002, p. 383, n. 62): "Sed est ne assensus verus? Dico quod nec verus nec falsus ante a, sed tunc primo est assensus verus quando ponitur res, quia assensum esse verum importat quod assensus sit, et quod illud sit in re cui assentitur."

39 Gualterus de Chatton, Reportatio, d. 38 (ed. Wey, Etzkorn, 2002, p. 355, n. 42): "Utrum autem cognitio Dei sit assensus vel scientia, et non solum apprehensio, posset dici quod cognitio Dei non est assensus nisi re posita; et quando res est futura, potest dici quod cognitio non est scientia." 
levels, but overlap to the point of coinciding on the ontological level of the res: the linguistic statement does not produce meaning but feeds on it, latching onto the things that the terms describe. With reference to this, Rondo Keele has talked of a "causal power" held by the res in relation to propositional complexa, and such a reading clearly implies a definite externalist reading of Chatton's epistemology. ${ }^{40}$

The case of prophecies is exemplary in this context. According to Chatton, God makes prophecies possible and truthful by inducing the prophet's mind to grant assent to states of affairs that, insofar as they are in the future, are beyond the human intellect's cognitive capacities. The assent given to the predicted things or state of affairs has a determinate truth only in the form of a causal inference, direct and externalist, linking the states of affairs and the statement describing them at a future time. God, on his part, does not cognize through language. Prophetic statements are but the means through which God witnesses and communicates a kind of knowledge that, by its very nature, is not discursive. ${ }^{41}$ Through the language, God does not know but, more properly, communicates.

In Chatton's view, propositional analysis is not an end in itself nor is it used to determine the statement's rules and their use in linguistic practice, which it is in Ockham's soft externalism. Rather, propositional analysis grounds any possibility of linguistic reference in the direct and necessary link between mental language and the ontological level of res. It is true that in the Reportatio and in particular in distinction 38, Chatton explores a solution in which future contingents can be true if they are correctly formulated from the point of view of propositional rules ${ }^{42}$ but it must be kept in mind that this does not mean that the linguistic plane is independent from that of the res.

${ }^{40}$ Keele, Pelletier, 2018: "We are to imagine, within the absolute power of God, whether the causal powers attributed to the kinds of entities in a given ontological snapshot would be sufficient to make the proposition in question turn out true. [...] if the causal powers of those entities are found wanting on the basis of consistency and yet the proposition in question were known to be true, then another kind of entity, with its attendant causal powers, would have to exist."

${ }^{41}$ Gualterus de Chatton, Reportatio, d. 40-41, q. 2 (ed. Wey, Etzkorn, 2002, p. 393, n. 3): "Certum est quod non sunt propositiones in mente Dei, nec assentit nostris propositionibus, igitur."

${ }^{42}$ See Bornholdt, 2017, p. 348. 


\section{From the Logic of Belief to the Logic of Witnessing}

The absence of an isomorphic relation between res and complexa makes simultaneity the necessary condition for a statement's truth. For Chatton, the assent that God induces in the prophet's mind is an assensum in absentia so to speak, but such an absence actually consists simply in being at a temporal removal from a state of affairs. Such an assent replaces the inferential chain or the causal power of the res that would normally produce assent in the intellect. In so doing, the prophet becomes a witness: in the present of his prophetic uttering, it is possible for men heeding it to grasp the concurrence between word and event that mundane temporality locates on two different levels, present and future.

This is why prophecies may not be simply considered as a sub-category of future contingents, that is rather a kind of thought experiment. Prophecy is a useful case study for thinking about how a community of believers can be semantically and pragmatically oriented to the path of salvation. Even though they are linguistically similar, prophetic statements have more "power" when compared to future contingents because of their theological meaning. What makes prophecy stand out is the peculiar figure of the prophet, who is placed within a complex conceptual framework based on the notions of assent and testimony. The former moves along the plane of mental language, in the form of linguistically formulated consent; the latter refers to a state of affairs that it guarantees and bears witness to. But assent and testimony intertwine, as the assensum is given to things and not to words, while testimony works as proof of states of affairs that is nonetheless formulated in linguistic form.

As Bornholdt rightly emphasizes, from the Reportatio to questions 27-29 of the Quodlibeta Chatton effectuates a crucial transition. ${ }^{43}$ He shifts his enquiry from the relationship between res and statements to the ground of the prophetic statements' truth-value. On our reading, the latter hinges on the role of the prophet as a witness. An indication of such a shift is Chatton's insistence on the issue of the deceiving God, which becomes central in Quodlibeta, questions 27-29. Indeed, at the beginning of question 27, Chatton writes:

43 Bornholdt, 2017, p. 424. 
The second problem is whether it lies in the power of any free agent whatsoever to make the sayings, oaths, and expressions of God false and that God deceives men and will make them believe something is going to be that will not be and that he knows will not be. ${ }^{44}$

If God can deceive us, then the truth and the value of the Holy Scriptures should be questioned, which is surely a crucial point.

In Chatton's view, knowledge is an inferential causal chain that can only start from a non-inferential knowledge of facts, i.e., an individual, existing res. On the basis of such a realist externalism, he rejects any hypothesis of a deceptive God or of an intuitive cognition of a non-existing thing. ${ }^{45}$ Chatton's insistence on this matter signals a shift of attention from prophetic statements to the prophet himself, who is not so much held responsible for the truth content of his own statements ( since this is guaranteed by the direct reference to the res) as much as he is considered the guarantor of those statements by to those who heed them and receive guidance from them. The absolute power of God is able to generate any sort of inferential chain, even one that leads one to assert with certainty the existence of something that does not exist. In this case, the role of the prophet consists in bearing witness to the direct knowledge chain represented by the prophetic revelation.

\section{Conclusion}

To conclude, a question arises: why does God decide to indicate future events through prophecies? Given that this cannot happen out of necessity, prophecies (and miracles) must be intended to help the deficient viator. Because of congenital weakness of intellect and wisdom, the viator needs conceptual clarity and the right moral guidance. Prophecies consist in telling so that human beings understand. They are signals on the path of the viator, ontological or linguistic marks that talk to man. Miracles show God's

${ }^{44}$ Gualterus de Chatton, Quodlibeta 26-29, q. 27, art. 1 (ed. Keele, pp. 187-188: 20-23): "Secundum dubium est utrum sit in potestate cuiuslibet agentis liberi facere dicta et iuramenta et locutiones Dei esse falsas et quod Deus decipit homines et fecerit eos credere aliqua esse ventura quae non fient et quae ipse scit non fore."

${ }^{45}$ Gualterus de Chatton, Quodlibeta 26-29, q. 27, art. 1 (ed. Keele, p. 199: 397-399): "Quantum ad istum articulum non concedo pro nunc Deum posse immediate alios fallere. Hoc enim apparet mihi modo magis irrationale quam alias apparuit. Iuxta ista quaero." 
absolute power and the divine origin of every possible order of the world. Prophecies show the righteous way of human action. Prophecies do not destabilize this divine order but rather reveal its coherence-most of all through rare cases and contingent events - showing how God's power is such that it can turn even the infraction of natural laws to the good. ${ }^{46}$ In fact, miracles and prophecies are not only events located in time, but also (and most of all) the proof of God's existence to humankind. Prophetic propositions are not only descriptive. They are "productive" of words about a current state of affairs that they contribute to determine (like performative speech acts). ${ }^{47}$ Prophecies must be intended within their theological finalities in the divine order of the world (like showing God's providential design of history and the path for human souls' salvation) and not relative to divine nature, which remains unchanged, but in a pragmatic context, that is the human path to salvation. God seconds it, disclosing counterfactual states of things, and giving viatores all the elements for the right conduct among those choices.

Though far from being exhaustive, our analysis allows us to draw some conclusions. First, the epistemological categories of internalism and externalism may function as guiding criteria for identifying the degree of ontological commitment displayed by a theory, and thus whether this theory leans more towards one pole of the cognitive relationship or the other-whether towards the cognizing subject or the cognized object. This allows one to establish a parameter or at least an indicator of the theory's efficacy and internal coherence, that is, which objects they allow us to know and whether there is consistency between the latter and their ontological commitment.

Secondly, Chatton's theory of assent is aimed at framing prophecies as pragmatic rules that are meant to guide the viator. Chatton's assertions and Ockham's claims about prophecies as implicit conditional statements seem to belong to the same theological milieu, confirming Brower-Toland's interpretation of a kind of debate between the two Franciscan theologians. ${ }^{48}$

Finally, while the different theories we examined both display varying degrees of internalism/externalism, they all rely on a fundamental realism that none of the authors seems to undermine, neither Chatton with his "hard" externalism, nor Ockham with his "soft" externalism. The existence of a solid

\footnotetext{
46 Normore, 1985, pp. 254-258.

47 Austin, 1962, pp. 4-11.

48 See Brower-Toland, 2015.
} 
metaphysical grounding, represented by the res and by necessity established in the divine order of the world, is the basic foundation for all the theories we examined, and not an issue they attempt to resolve. Such theories all share the same realist framework - characterized by that common "search of simplicity" specific to the conversational community of 13th-14th century theologians described by Friedman in the context of Trinitarian theology and extended here, as we have seen, to the debates about prophecies. These theories differ from one another simply by virtue of their degree of oscillation within it. Here is where all the difference in the contemporary debate on externalism lies; in today's discussion the situation is reversed and the issue of the ontological grounding is precisely the point of contention.

\section{Bibliography}

\section{Primary Sources}

Aristoteles (2016). Analytica Posteriora. In: Organon. Ed. M. Migliori. Milano: Bompiani.

Aristoteles (2016). De interpretatione. In: Organon. Ed. M. Migliori. Milano: Bompiani.

Gualterus de Chatton (2002). Reportatio super Sententias: super Librum I. Ed. J.C. Wey, G.J. Etzkorn. Turnhout: Brepols.

Gualterus de Chatton. Quodlibeta 26-29. Excerpt from Paris BN MS lat. 15805, ff. 54ra-6orb. 26.

Guillelmus de Ockham (1974). Summa logicae. In: Opera Philosophica I. Ed. P. Boehner, G. Gál, S. Brown. New York: St. Bonaventure.

Guillelmus de Ockham (1978). Tractatus de praedestinatione et de praescientia Dei respectu futurorum contingentium. In: Opera Philosophica II. Ed. P. Boehner, S. Brown. New York: St. Bonaventure.

Guillelmus de Ockham (1980). Quodlibeta Septem. In: Opera Theologica IX. Ed. J.C. Wey. New York: St. Bonaventure.

Guillelmus de Ockham (1985). Expositio in libros physicorum. In: Opera Philosophica IV. Ed. V. Richter, G. Leibold. New York: St. Bonaventure.

William of Ockham (1969). Predestination, God's Foreknowledge, and Future Contingents. Ed. M. McCord Adams, N. Kretzmann. New York: Appleton Century Crofts. 
Thomas de Aquino (1970-1976). Quaestiones disputatae de veritate. Ed. A. Dondaine. In: Sancti Thomae de Aquino doctoris angelici, Opera Omnia, iussu impensaque Leonis XIII P.M. edita, cura et studio fratrum praedicatorum. Roma: Editori di San Tommaso.

\section{Secondary Sources}

Austin, J.L. (1962). How to Do Things with Words. Oxford: Oxford University Press.

Bornholdt, J. (2017). Walter Chatton on Future Contingents. Between Formalism and Ontology. Leiden: Brill.

Brower-Toland, S. (2007). "Intuition, Externalism and Direct Reference in Ockham". History of Philosophy Quarterly, 24, 317-336.

Brower-Toland, S. (2015). "How Chatton Changed Ockham's Mind: William Ockham and Walter Chatton Objects and Acts of Judgment”. In: G. Klima, Intentionality, Cognition, and Mental Representation in Medieval Philosophy (pp. 204-234). New York: Fordham University Press.

Brower-Toland, S. (2017). "Causation and Mental Content: Against the Externalist Reading of Ockham". In: J. Pelletier, M. Roques (eds.), The Language of Thought in Late Medieval Philosophy. Essays in Honour of Claude Panaccio (pp. 59-80). Dordrecht: Springer.

Courtenay, W.J. (1972). "The King and the Leaden Coin: The Economic Background of 'sine qua non' Causality”. Traditio, 28, 185-209.

Courtenay, W.J. (1985). "The Dialectic of Omnipotence in the High and Late Middle Ages". In: T. Rudavsky (ed.), Divine Omniscience and Omnipotence in Medieval Philosophy (pp. 243-269). Dordrecht: Reidel.

Courtenay, W.J. (1990). Capacity and Volition. Bergamo: Lubrina.

Dummett, M. (1964). “Bringing About the Past”. Philosophical Review, 73, 338-359.

Fedriga, F. (2019). "Mental Acts, Externalism and Fiat Objects: An Ockhamist Solution'. In: R. Davies (ed.), Natural and Artifactual Objects in Contemporary Metaphysics (pp. 19-47). London: Bloomsbury Academic.

Fedriga, R., Limonta, R. (2015). "Prophetae non dixerunt falsum. Spazio percettivo e spazio semantico nelle teorie della profezia di Pietro Aureolo e Guglielmo di Ockham". Documenti e studi sulla tradizione filosofica medievale, 26, 399-431.

Fedriga, R., Limonta, R. (2020). Il Trattato sulla predestinazione e prescienza divina riguardo ai futuri contingenti di Guglielmo di Ockham. Roma: Città Nuova. 
Freddoso, A., Kelley, F. (eds.) (1991). William of Ockham's Quodlibetal Questions. New Haven: Yale University Press.

Friedman, R.L. (2013). Intellectual Traditions at the Medieval University: The Use of Philosophical Psychology in Trinitarian Theology among the Franciscans and the Dominicans, 1250-1350. Leiden: Brill.

Gelber, H.G. (2004). It Could Have Been Otherwise. Contingency and Necessity in Dominican Theology at Oxford 1300-1350. Leiden-Boston: Brill.

Grellard, C. (2014). De la certitude volontaire. Débats nominalistes à la fin du Moyen Âge. Paris: Publications de la Sorbonne.

Karger, E. (1999). “Ockham's Misunderstood Theory of Intuitive and Abstractive Cognition". In: P.V. Spade (ed.), The Cambridge Companion to Ockham (pp. 204-226). Cambridge: Cambridge University Press.

Karger, E. (2004). "Ockham and Wodeham on Divine Deception as a Skeptical Hypothesis". Vivarium, 2, 225-236.

Karger, E. (2015). "Was Adam Wodeham an Internalist or an Externalist?" In: G. Klima (ed.), Intentionality, Cognition, and Mental Representation in Medieval Philosophy (pp. 186-203). New York: Fordham University Press.

Keele, R., Pelletier, J. (2018). "Walter Chatton”. In: E. Zalta (ed.), The Stanford Encyclopedia of Philosophy. Retrieved from: https://plato.stanford.edu/ archives/fall2018/entries/walter-chatton/.

Klima, G. (2010). "Indifference vs. Universality of Mental Representation in Ockham, Buridan and Aquinas". Quaestio. Later Medieval Perspectives on Intentionality, 10, 99-110.

Normore, C. (1985). "Divine Omniscience, Omnipotence and Future Contingents. An Overview". In: T. Rudavsky (ed.), Divine Omniscience and Omnipotence in Medieval Philosophy (pp. 16-19). Dordrecht-Boston-Lancastr: Reidel.

Normore, C. (2017). “Likeness Stories”. In: J. Pelletier, M. Roques (eds.), The Language of Thought in Late Medieval Philosophy: Essays in Honour of Claude Panaccio (pp. 81-94). Dordrecht: Springer.

Panaccio, C. (2010). "Intuition and Causality: Ockham's Externalism Revisited". Quaestio, 1, 241-243.

Panaccio, C. (2014). “Ockham: Intuition and Knowledge”. In: L. Osbeck, B.S. Held (eds.), Rational Intuition: Philosophical Roots, Scientific Investigations (pp. 55-74). Cambridge: Cambridge University Press. 
Panaccio, C. (2015). “Ockham Externalism”. In: G. Klima (ed.), Intentionality, Cognition, and Mental Representation in Medieval Philosophy (pp. 166-185). New York: Fordham University Press.

Pappas, G. (2014). "Internalist vs. Externalist Conceptions of Epistemic Justification". In: E. Zalta (ed.), The Stanford Encyclopedia of Philosophy. Retrieved from: https://plato.stanford.edu/archives/fall2014/entries/justep-intext.

Pasnau, R. (1997). Theories of Cognition in the Later Middle Ages. Cambridge: Cambridge University Press.

Perini Santos, E. (2006). La théorie ockhamienne de la connaissance évidente. Paris: Vrin.

Piron, S. (2014). "La parole prophétique". In: I. Rosier-Catach, N. Beriou, J.-P. Boudet (eds.), Le pouvoir des mots au Moyen Âge (pp. 255-286). Turnhout: Brepols.

Rodolfi, A. (2016). "Cognitio Obumbrata”. Lo statuto epistemologico della profezia nel secolo XIII. Firenze: Sismel-Edizioni del Galluzzo.

Slotemaker, J. (2015). "Walter Chatton and Adam Wodeham on Divine Simplicity and Trinitarian Relation". Quaestio, 15, 689-697.

Tachau, K.H. (1988). Vision and Certitude in the Age of Ockham. Leiden: Brill.

Torrell, J.-P. (1992). Recherches sur la théorie de la prophétie au Moyen Âge. XIVXIV siècles. Études et textes. Fribourg: Editions Universitaires.

Vauchez, A. (1990). Les textes prophétiques et la prophétie en Occident (XIIe-XVIe siècle). Roma: Mélanges de l'Ecole Français de Rome.

\begin{abstract}
The subject of this article is the intertwining between Walter Chatton and William of Ockham's theories about the cognitive nature of prophetic statements, a topic in the theological debate of the early 14th century, where the two Franciscans, albeit from different positions, played a crucial role. Starting from recent interpretations of Chatton and Ockham's cognitive theory in terms of the distinction between externalism and internalism, and from a reading of some sources where the topic of prophecy is crucial (for Chatton: Reportatio Super Sententias, I, dd. 38-39, the less investigated distinction 41 and Quodlibeta, questions 26-29; for Ockham: Tractatus de praedestinatione et de praescientia Dei respectu futurorum
\end{abstract}


contingentium, question 1 and Quodlibeta, question 4), we will apply the externalism/ internalism distinction to the case study of prophetic statements. On the basis of the epistemological questions about prophecies, future contingents and divine foreknowledge, we will show the outcomes as pragmatic rules of this kind of statements in both conceptual frameworks analyzed. 